LETTER TO JMG

\title{
Mutations in PHF8 are associated with X linked mental retardation and cleft lip/cleft palate
}

\author{
F Laumonnier* S Holbert*, N Ronce, F Faravelli, S Lenzner, C E Schwartz, J Lespinasse, H Van \\ Esch, D Lacombe, C Goizet, F Phan-Dinh Tuy, H van Bokhoven, J-P Fryns, J Chelly, H-H Ropers, \\ C Moraine, B C J Hamel, S Briault
}

J Med Genet 2005;42:780-786. doi: 10.1136/jmg.2004.029439

Truncating mutations were found in the PHF8 gene (encoding the PHD finger protein 8) in two unrelated families with $X$ linked mental retardation (XLMR) associated with cleft lip/ palate (MIM 300263). Expression studies showed that this gene is ubiquitously transcribed, with strong expression of the mouse orthologue Phf8 in embryonic and adult brain structures. The coded PHF8 protein harbours two functional domains, a PHD finger and a JmjC (Jumonji-like C terminus) domain, implicating it in transcriptional regulation and chromatin remodelling. The association of XLMR and cleft lip/palate in these patients with mutations in PHF8 suggests an important function of PHF8 in midline formation and in the development of cognitive abilities, and links this gene to XLMR associated with cleft lip/palate. Further studies will explore the specific mechanisms whereby PHF8 alterations lead to mental retardation and midline defects.

X linked mental retardation (XLMR) is an inherited condition that causes failure to develop cognitive abilities because of mutations in several genes on the $\mathrm{X}$ chromosome. XLMR is a highly heterogeneous condition affecting around 1.6/1000 males, with a carrier frequency of 2.4/1000 females. ${ }^{12}$ More than 200 XLMR conditions have been described, ${ }^{3}$ which can be divided as follows:

- non-syndromic forms (MRX), in which mental retardation is the only clinical manifestation; 81 MRX families have been reported so far;

- syndromic forms (MRXS), in which mental retardation is associated with biochemical abnormalities, neurological features, or recognisable physical signs such as skeletal abnormalities or facial dysmorphy. ${ }^{34}$

Both MRX and MRXS genes have been located at various regions on the $\mathrm{X}$ chromosome. To date, more than 40 genes responsible for MRXS and 24 genes responsible for MRX have been cloned. ${ }^{35}$ Furthermore, it has been shown that mutations in a single gene-such as $A R X^{67} M E C P 2,{ }^{69}$ or $R S K 2^{10}$ - could lead to a wide spectrum of clinical features that encompass both MRX and MRXS conditions. Based on the distribution of linkage intervals in 125 unrelated MRX families, Ropers and others previously showed that $30 \%$ of all mutations cluster on proximal Xp. ${ }^{11}$ We report here the identification of a new gene, PHF8 (PHD finger protein 8), located in Xpll and mutated in families with XLMR associated with cleft lip/cleft palate.

\section{METHODS}

\section{Patients and families}

The family pedigrees are shown in figs 2 and 3. DNA and RNA were extracted from blood samples and immortalised lymphoblastoid cell lines (family N42) that were established from peripheral lymphocytes using standard protocols.

\section{Fluorescence in situ hybridisation (FISH)}

BACs on chromosome Xpl1.21 were selected from Ensembl database (http://www.ensembl.org) and the UCSC genome browser (http://genome.ucsc.edu) and obtained from the CHORI Institute (http://bacpac.chori.org). Hybridisation experiments were carried out as previously described. ${ }^{12}$

\section{Mutation analysis of PHF8}

Polymerase chain reaction (PCR) was carried out in $50 \mu \mathrm{l}$ reaction volumes containing $100 \mathrm{ng}$ of genomic DNA from the patients, $10 \mathrm{pM}$ of each primer, $1.25 \mathrm{mM}$ of dNTPs, $0.5 \mathrm{U}$ Taq DNA polymerase (Promega, Madison, Wisconsin, USA), and $1.5 \mathrm{mM} \mathrm{MgCl}_{2}$. An initial denaturation of five minutes at $94^{\circ} \mathrm{C}$ was followed by 30 cycles of one minute at $94^{\circ} \mathrm{C}$, one minute of annealing, a one minute extension at $72^{\circ} \mathrm{C}$, and a final extension step of seven minutes at $72^{\circ} \mathrm{C}$. The products were then checked on a $1.5 \%$ agarose gel to verify amplification before analysis by denaturing high performance liquid chromatography (DHPLC) using the WAVE 3500 HT system (Transgenomic, Santa Clara, California, USA). For each amplified exon, melting profiles and temperatures were predicted by the Transgenomic Navigator software version 1.5.1 (DHPLC conditions available upon request). Pairs of amplified fragments from patient and control PCR products were pooled, denatured at $95^{\circ} \mathrm{C}$ for three minutes, and cooled to $40^{\circ} \mathrm{C}$ in decreasing increments of $0.05^{\circ} \mathrm{C}$ per second. The products were then injected and eluted with an acetonitrile gradient at a flow rate of $1.5 \mathrm{ml} /$ min, with a mobile phase composed of two buffers (buffer A, 0.1 M triethylammonium acetate or TEAA; buffer B, $0.1 \mathrm{M}$ TEAA with $25 \%$ acetonitrile). For each sample pair that showed an abnormal elution profile, the PCR products were purified and sequenced on an ABI377 DNA sequencer (Perkin Elmer, Norwalk, Connecticut, USA).

\section{RT-PCR and expression studies}

For reverse transcriptase polymerase chain reaction (RT-PCR) experiments on mouse material, total RNA samples were prepared from embryonic, newborn, and postnatal (P60) mouse brains. Cells were derived from brains of randomly bred Swiss mice. Glial cells were from newborn murine cerebral hemispheres, and $95 \%$ of the cells were identified as type 1 astrocytes. Cultures of neuronal cells were set up from single cell suspension of fetal brains at 15 days of gestation. Cultures consisted predominantly of neurones (>95\%).

Abbreviations: DHPLC, denaturing high performance liquid chromatography; FISH, fluorescence in situ hybridisation; MRX, nonsyndromic forms of $X$ linked mental retardation; MRXS, syndromic forms of $X$ linked mental retardation; XLMR, $X$ linked mental retardation 


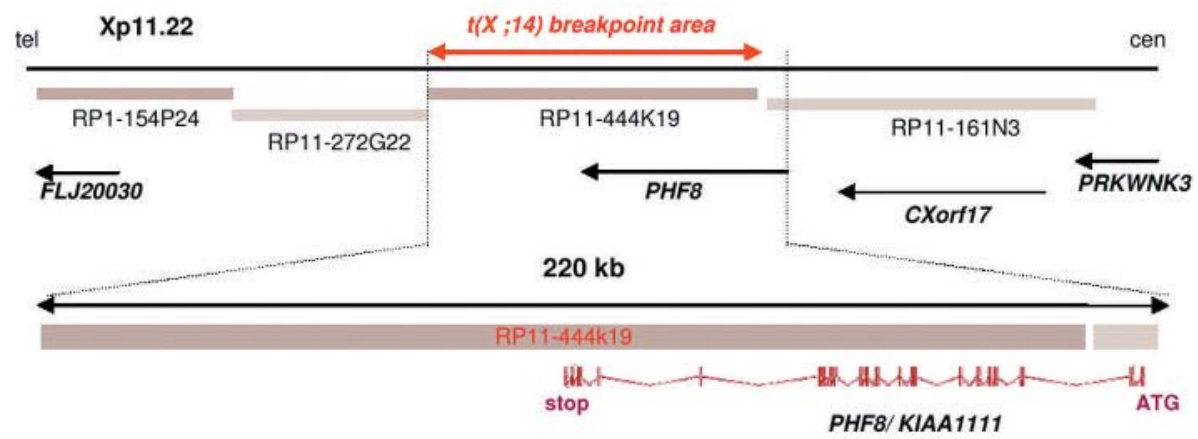

Figure 1 Characterisation of the PHF8 gene. Transcriptional map of the $X p 11$ area including the $X$ chromosomal breakpoint of the $f(X ; 14)$ translocation. The minimum critical region is estimated at $220 \mathrm{~kb}$ and includes the PHF8 gene that is transcribed from centromere to telomere.

Amplification by RT-PCR was carried out according to standard procedures.

Non-radioactive in situ hybridisation was undertaken as described elsewhere. ${ }^{19}$ Mouse embryonic (16 days postconception) and adult brain sections were hybridised with the sense and the antisense RNA generated from the 3' untranslated part of $P h f 8$.

\section{RESULTS}

Characterisation of the PHF8 gene and identification of mutations in families with XLMR and cleft lip/cleft palate

We previously investigated a balanced translocation $(X ; 14)(\mathrm{p} 11.2 ; \mathrm{pl0})$ found in two half sisters and their mother who all had non-syndromic mental retardation and epilepsy. To establish the physical location of the chromosomal aberration, we carried out FISH experiments with BAC clones obtained from the CHORI institute. The DNA clones were prepared by standard techniques, were labelled by nick translation, and were used as probes in FISH, as previously described. ${ }^{12}$ The breakpoint of the chromosome 14 was located on the short arm. As rearrangements of the short arms of acrocentric chromosomes, particularly robertsonian translocations, do not lead to any abnormal phenotypes, we suggested that the $\mathrm{Xp}$ chromosomal breakpoint would probably be involved in the phenotype of the patients. We localised the Xp breakpoint within the BAC clone RP13444K19 (GenBank Accession number AL732374) (fig 1). BLAST analysis of the genomic region revealed the presence of only one cDNA called KIAA1111 (GenBank accession number AB029034). It is expressed in human adult brain and represents a novel gene named PHF8 (PHD finger protein 8) (GenBank accession number NM_015107) (fig 1).

Based on these findings, the PHF8 gene appeared to be a strong candidate for XLMR. We screened the PHF8 gene for mutations in 40 families with XLMR and with a linkage interval covering the candidate region in Xpll. The families were collected by the EuroMRX consortium ( 24 families) and the Greenwood Genetic Center/University of Miami XLMR study (16 families). ${ }^{13}$ We analysed the coding sequence of PHF8 by PCR experiments using genomic DNA and primers that amplified both the exonic sequences and the exon-intron junctions (table 1).

Initially, we identified a mutation in PHF8 in family N42, previously described by Siderius et al. ${ }^{14}$ Affected males of this family have a syndromic form of XLMR associated with cleft

\begin{tabular}{|c|c|c|c|}
\hline Exon & Forward primer $\left(5^{\prime} \rightarrow 3^{\prime}\right)$ & Reverse primer $\left(5^{\prime} \rightarrow 3^{\prime}\right)$ & $\begin{array}{l}\text { Annealing temperature } \\
\text { ('C) }\end{array}$ \\
\hline 1 & tcaagtcacttggcttctcga & atgagaggaggtgaactcggt & 62 \\
\hline 2 & actgagggittggtgcaagg & gagagcaagtgaacacacctg & 63 \\
\hline 3 & acag cactg ftctagacctca & cctttcctttgtctctcctct & 56 \\
\hline 4 & gctcaggcctttigttcttggt & gggaaagctgggaagaggt & 63 \\
\hline 5 & gtggcagcctccaataag & aaacagattggaggggaagg & 59 \\
\hline 6 & ggactgatgaggggacaagaga & agagaaacacgaatatacactag & 59 \\
\hline 7 & gctgtggggtaltttattcagge & gattcaaaatg fttctgtgctgc & 59 \\
\hline 8 & gtttlggagcatgggagaaa & Haatatgctgtggggccaa & 60 \\
\hline 9 & ttgagatgagtaggtagtggaga & ccttctacattatactcctcact & 58 \\
\hline 10 & catccagaacaaaacctgattc & tatcatgtcttgactgcg ttac & 59 \\
\hline 11 & gittgtttlaacaaaagitccca & ctctccaaaacatctaccca & 60 \\
\hline 12 & $\begin{array}{l}\text { tctccattgaaltgccttgg } \\
\text { tis }\end{array}$ & atgctaactgcagaggcctaa & 58 \\
\hline 13 & aggaacagacctctgctgitta & ggatagcctgctIItIgaaac & 59 \\
\hline 14 & ccagtgaaaccagagggaact & ctgtctcagtgg catattacc & 59 \\
\hline 15 & cttgctagcgactaacaatac & tccgtctcaaaacaaacaaaca & 62 \\
\hline 16 & Gtattlggctgaaatgctaatc & ccaactagaatgacaatctgtc & 59 \\
\hline 17 & tcatcgcccctgtactggg & ctgattggctgacctggcac & 64 \\
\hline 18 & gatgaccgatttactctgacag & gatggagactgggactgagg & 64 \\
\hline 19 & tcattctatcttcaccettig & catccttgtctalttcctcct & 59 \\
\hline 20 & agagcttggaggtagggaat & tctaagtcaaactgctattagt & 59 \\
\hline 21 & gtctag ttag ttcctttcctgg & taagatccttcg gttctacaacc & 59 \\
\hline 22 & Htggtgccagattlgatgttg & gaaggcagg caggatgctcta & 63 \\
\hline
\end{tabular}


A

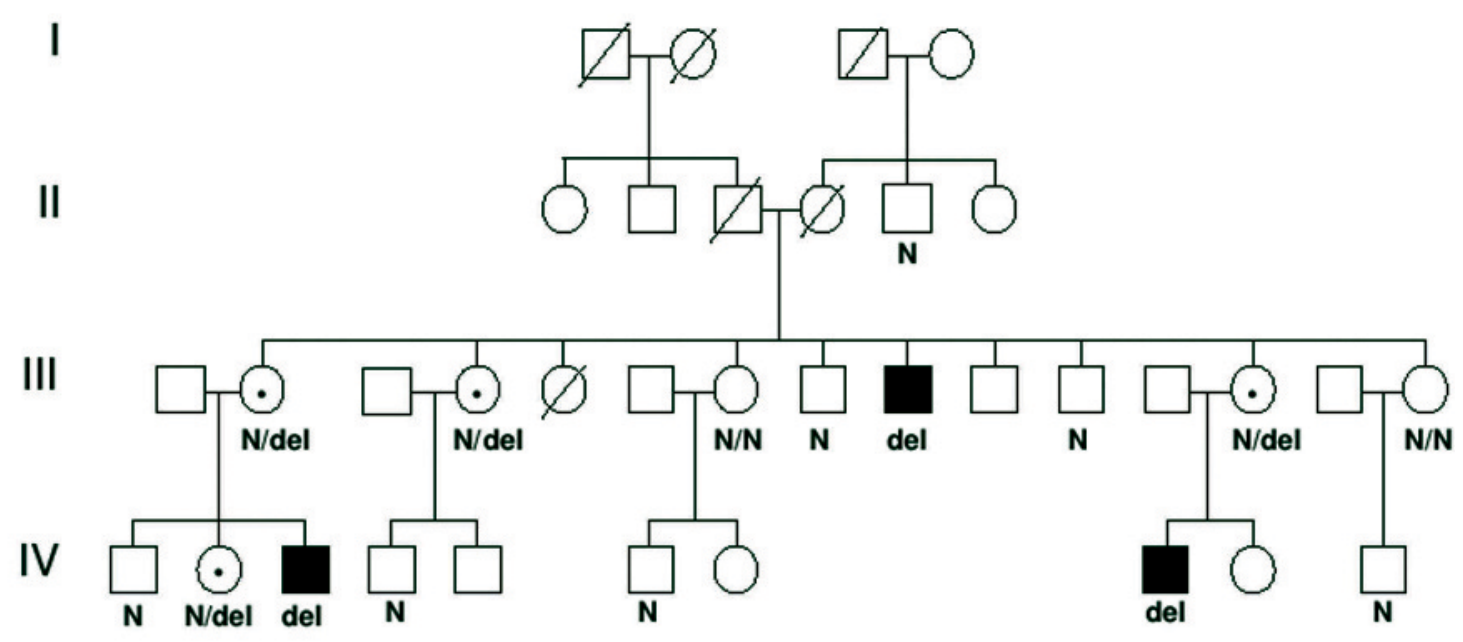

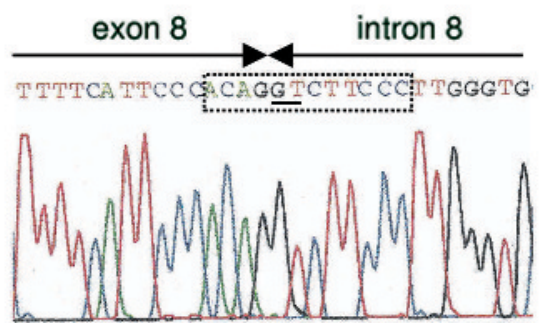

Control

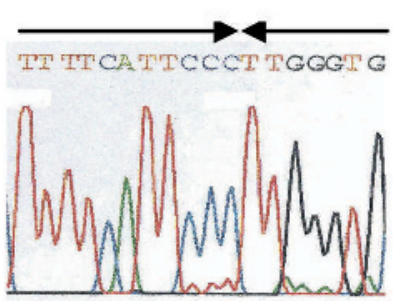

Affected

B

$$
\text { ACAGgtcttccC }
$$

...CAAGGACAGACACTTTTCATTCCC ttgggtgcttctgggagggtttggggagggtggaaagaagaagggagcttttggccccacagcatattaatctga

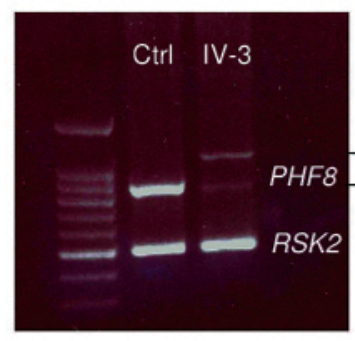

4 Q G Q T L F I P L GAS GR VW G G W KE E G SFW P H S I L I X Transcript 2 (major)

Transcript 1 (minor)

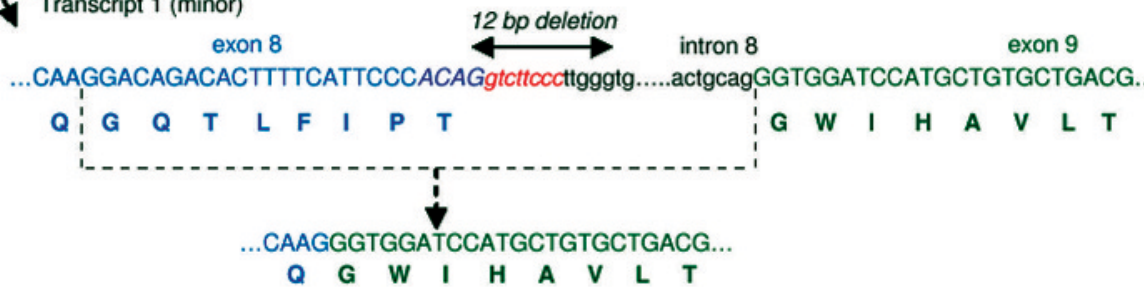

Figure 2 Mutation of PHF8 in family N42 associated with X linked mental retardation and cleft lip/palate. (A) Pedigree of family N42 showing the affected male patients (black squares) who carry the 12 bp deletion (del), the unaffected male and female patients (white squares, N), and the heterozygous female carriers (N/del). The sequencing electrophoregrams show that the deletion causes the elimination of the splice donor site of intron 8. (B) Reverse transcriptase polymerase chain reaction (RT-PCR) and sequencing results of both PHF8 transcripts expressed in lymphoblastoid cell lines of individual IV-3. One microgram of RNA from affected individual IV-3 and control was reverse transcribed followed by polymerase chain reaction (PCR) with one forward primer (5'- TAACCTGTGGAGACACCGAA-3') located in exon 7, one reverse primer (5'-AAGAGCAGATGATCGCAACT$3^{\prime}$ ) located in intron 8, and a second reverse primer (5'-CTAGTGCTAATGCACATCAG-3'). In the same reaction, a RSK2 transcript fragment (486 bp) was amplified as an internal control, ${ }^{10}$ using the following primers (forward 5'-GGACAGCAAATTATGGATGA-3' and reverse 5'-

CTAGTGCTAATGCACATCAG-3'). The PCR products were migrated in a $1.2 \%$ agarose gel and showed two PHF 8 transcripts in the affected individual, one weakly expressed transcript (transcript 1 fragment, $822 \mathrm{bp}$ ) with the $8 \mathrm{bp}$ deletion compared to the control, and a higher expressed transcript (transcript 2 fragment, $1068 \mathrm{bp}$ ) composed of coding sequence of exon 7 extended into intron 8, and absent in the control lane. 

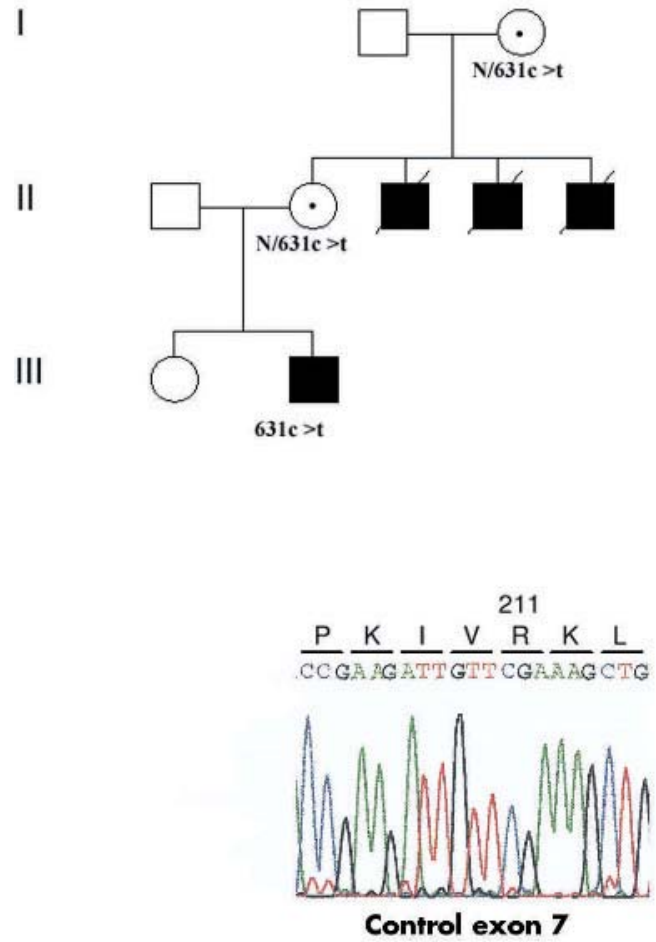

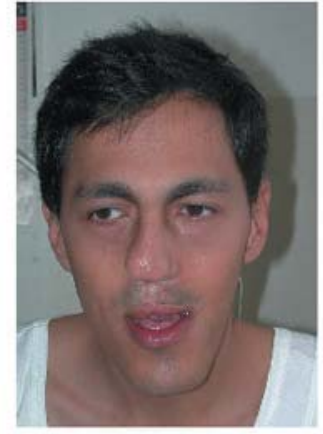

III-2

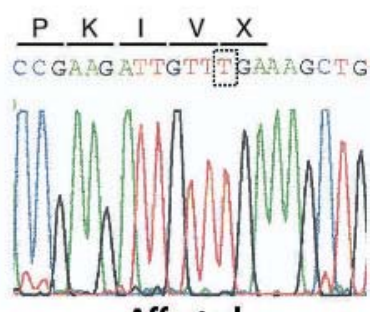

Affected

Figure 3 631C $\rightarrow T(R 211 X)$ mutation in family 2. Representation of the pedigree of the Italian family and facial features of patient III-2 (written consent from the patient and his legal guardian was obtained for publication of the images in print and online). The chromatogram of the mutant sequence is shown, along with a control sequence. A C $\rightarrow$ T substitution located in exon 7 was identified in blood DNA from patient III-2. The carrier females (I-2 and II-2) are heterozygous for this mutation. (Photograph reproduced with patient's consent.)

lip/cleft palate. The family consists of three affected males in two generations (III-9, IV-3, and IV-8; fig 2A), who showed, at the time of clinical examination, mild to borderline mental retardation, minor facial anomalies such as a long face and broad nasal tip, cleft lip/cleft palate in two (bilateral for individual III-9 and unilateral for IV-3), and large hands (75th to 97th centile for IV-3; $>97$ th centile for IV-8 and III9). Previous linkage analysis assigned the putative XLMR gene to Xp11.3-q21.3, between the markers DXS337 and DXS990, defining a linkage interval of $25 \mathrm{cM} .{ }^{14}$ The mutation analysis for PHF8 in the three affected males of N42 family revealed a 12 base pair (bp) deletion at the exon 8/intron 8 junction (fig 2A), that was predicted to suppress the splice donor site of intron 8. To test the presence of an abnormal splicing event, RT-PCR was carried out on RNA extracted from lymphoblasts of both the affected individuals and controls. The RT-PCR analysis showed the presence of two transcripts in the affected individuals. One was a very weakly expressed transcript composed of a portion of exon 8, joined to the normal exon 9. A higher expressed second band was a transcript in which the coding sequence extended into intron 8 up to a stop codon (fig 2B).

Based on this finding, additional screening of cases with mental retardation plus cleft lip/cleft palate was undertaken. As a result, another mutation was found in a second family with males who had mental retardation and clinical features similar to the N42 family (fig 3). The propositus (III-2) was the second child of two unrelated parents. Two maternal uncles died in the neonatal period and the mother stated they had bilateral cleft lip and palate. A third maternal uncle, who died in a car accident, suffered from mild mental retardation without clefting. The propositus was born by spontaneous delivery after an uneventful pregnancy. At birth, his weight was $2550 \mathrm{~g}$ ( 5 th to 10th centile), length
$47 \mathrm{~cm}$ (10th to 25th centile), and head circumference $33 \mathrm{~cm}$ (5th to 10th centile). At 25 years old, his weight was $60.5 \mathrm{~kg}$ (25th to 50th centile), and his height was $178 \mathrm{~cm}$ (75th centile). He had mental retardation and minor facial dysmorphia with a scar from an operated cleft lip (fig 3). He also had long hands $(20 \mathrm{~cm},>97$ th centile) with long and thin fingers, and flat feet with long and thin toes. Computed tomography and magnetic resonance imaging were normal. Cytogenetic analysis revealed a normal 46, XY karyotype, and molecular analysis of the FMRI CCG expansion, subtelomeric rearrangements and 22q1l deletion by FISH were negative.

The analysis of the coding sequence of PHF\& revealed the presence of a nonsense mutation, p.R211X (c.631C $\rightarrow$ T), in exon 7 (fig 3), leading to a predicted truncated protein of 211 amino acids compared with the normal protein of 1024 amino acids. We could not test the expression of the altered transcript as only genomic DNA from the propositus III-2, his mother, and grandmother were available.

The two mutations described above were present in all tested affected family members. All female carriers in the respective families were heterozygous. The sequence changes were not found in 100 healthy unrelated male and 100 unrelated healthy females (300 X chromosomes), making it unlikely they were rare polymorphisms.

We also analysed the PHF8 gene in a male patient of a family affected by the Pallister W syndrome (OMIM $311450)^{15}$-which is characterised by median cleft upper lip, central nervous system involvement with strabismus and spasticity, and moderate to severe mental retardation-and in four sporadic male individuals having a similar phenotype to the two mutated families (that is, mental retardation and cleft lip/cleft palate). However, no mutations in the coding sequence of the PHF\& gene were found. 
A

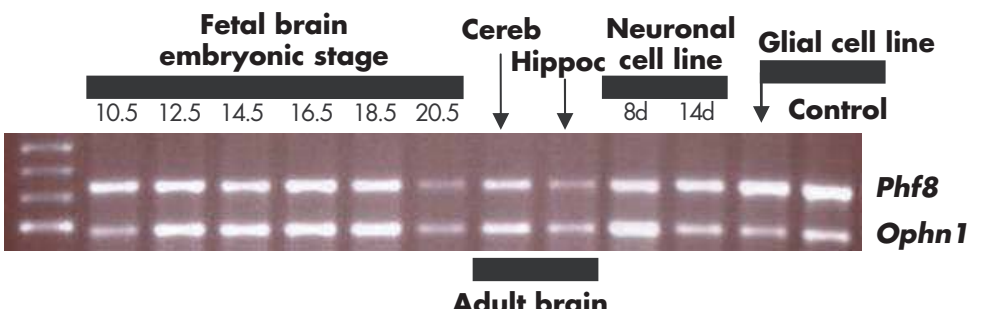

Figure 4 Expression studies of the mouse orthologue Phf8. (A) Reverse transcriptase polymerase chain reaction analyses carried out on mouse RNA samples extracted from brains at different embryonic stages, adult brain structures (cerebellum and hippocampus), and neuronal and glial cell lines. Phf8 was expressed in all tested tissues. (B) In situ hybridisation on mouse embryo (16.5 days postconception (pc) and adult brain section. Nonradioactive in situ hybridisation was carried out as described elsewhere. ${ }^{19}$ Mouse embryonic and adult brain sections were hybridised with the sense and the antisense RNA probes generated from the 3' region of the Phf8 gene (cDNA sequence AK122447; primers forward [5'-

AAGGAATGAGGAGGAGCAACA-3'] and reverse [5'-TCACCACACCCTCTTCAGAG-3']; amplicon of 620 bp). Mouse total embryo: L, lung; MB, midbrain; MO, medulla oblongata; NC, neopallial cortex; OE, olfactory epithelium; PFV, primordium of follicles of vibrissae; PIT, primordium of incisor tooth; SG, submandibular gland; T, thymus gland. Mouse adult brain: Ce, cerebellum; Co, cortex; GL, granular layer; H, hippocampus; ML, molecular layer; OB, olfactory bulb; St, striatum; WM, white matter.

\section{RT-PCR and expression studies}

PHF8 is a novel human zinc finger gene of unknown function. The gene is composed of 22 exons. The transcript has a length of $5776 \mathrm{bp}$ and an open reading frame of 3075 bp. The PHF8 transcript shows a ubiquitous expression pattern as tested by expressed sequence tag analyses and northern blot hybridisation (results not shown). PHF8 domains are also highly conserved among orthologues in other species, including mouse and $X$ laevis.

To further investigate PHF8 expression in adult brain and in primary cultures of mouse neuronal and astroglial cells during development, we derived appropriate primers from 
481 RLSLPSKNGS KKKGLKPKEL FKKAERKGKE SSALGPAGQL SYNLMDTYSH QALKTGSFQK

541 AKFNITGACL NDSDDDSPDL DLDGNESPLA LLMSNGSTKR VKSLSKSRRT KIAKKVDKAR

601 LMAEQVMEDE FDLDSDDELQ IDERLGKEKA TLIIRPKFPR KLPRAKPCSD PNRVREPGEV

661 EFDIEEDYTT DEDNVEGVEG KLGNGSGAGG ILDLLKASRQ VGGPDYAALT EAPASPSTQE

721 AIQGMLCMAN LQSSSSSPAT SSLQAWUTGG QDRSSGSSSS GLGTVSNSPA SQRTPGKRPI

781 KRPAYWRTES EEEEENASLD EQDSLGACFK DAEYIYPSLE SDDDDPALKS RPKKKKNSDD

841 APWSPKARVT PTLPKQDRPV REGTRVASIE TGLAAAAAKL AQQELQKAQK KKYIKKKPLL

901 KEVEQPRPQD SNLSLTVPAP TVAATPQLVT SSSPLPPPEP KQEALSGSLA DHEYTARPNA

961 FGMAQANRST TPMAPGVFLT QRRPSVGSQS NQAGQGKRPK KGLATAKQRL GRILKIHRNG

$1021 \mathrm{KLLL}$

Figure 5 Annotated sequence of the human PHF8 protein. PHF8 protein sequence showing mutations and regions of functional importance. The positions of the mutations are marked by arrows. PHD fingers (amino acid position 7-53) and JmiC (amino acid position 195-294) domains are represented by shaded regions. Putative NLS sequences are underlined and italicised.

the mouse homologous gene and studied its expression by RT-PCR. Figure 4A shows RT-PCR amplification of the mouse Phf8 mRNA and Ophnl mRNA used here as a control. ${ }^{16}$ These results showed a relatively high level of expression in the embryonic and early postnatal stages of brain development. The expression spectrum of Phf8 in sections of mouse embryos is rather ubiquitous, especially in brain structures, with a higher expression in neopallial cortex, midbrain, and the dorsal part of the medulla (fig 4B). The gene is also expressed in the olfactory epithelium, the submandibular gland, and the primordium of follicles of the vibrissae. In addition to the expected expression of Phfs in fetal brain at different embryonic stages, a higher expression is observed in cerebellum (granular layer) and hippocampus in adult brain (fig 4B), which are structures potentially involved in the physiological processes underlying memory and learning abilities.

\section{DISCUSSION}

We report here the identification of the human PHF8 gene located in Xpl1.21 and encoding a new member of the PHD finger protein family. We showed that truncating mutations of PHF8 led to XLMR with or without cleft lip/cleft palate in two unrelated families, with a large intrafamilial phenotypic heterogeneity, ranging from non-specific mental retardation (N42 family: individual IV-8; Italian family: individual II-5) to mental retardation and cleft lip/cleft palate (other affected males of both families).

The PHF8 protein is composed of 1024 amino acids and contains a PHD zinc finger domain (amino acid positions 753) and a Jumonji C (JmjC) domain (positions 195-294, fig 5), which are highly conserved among orthologues in other species, including mouse and X laevis. The murine Phf8 encodes a putative 1005 amino acid protein (Genbank accession number BAC65729) and shares $94 \%$ of identity at the amino acid level with human PHF8. Furthermore, BLAST analysis identified an orthologue in yeast (Genbank accession number NP_010971), suggesting that the PHF8 protein has been conserved during evolution.

As the large majority of PHD finger-containing proteins are localized in the nucleus, we looked for protein sorting signals using the PSORTII prediction program. We found four putative nuclear localization signals (NLS) with a 4/7 residues pattern, and two bipartite NLS (fig. 5), suggesting that PHF8 is very likely a nuclear protein. Furthermore, the predicted truncated proteins in the two affected families lack five NLS, which probably results in a cytoplasmic localisation of these truncated proteins thereby altering their function.

PHD finger genes are thought to belong to a diverse group of transcriptional regulators affecting eukaryotic gene expression by influencing chromatin structure. This family is composed of more than 15 members and one of them, PHF6, has already been implicated in a syndromic form of XLMR known as the Börjeson-Forssmann-Lehman syndrome (MIM 301900). ${ }^{17}$

More than 250 proteins share the jmjC domain (Interpro accession number IPR003347). JmjC-domain containing proteins have been implicated in apoptosis and in chromatin remodelling. ${ }^{18}$ The secondary structure of the JmjC domain predicts an enzyme activity. Its frequent association with DNA binding motifs, such as PHD finger domains, and its 
putative chromatin modification activities suggest a role in regulating the integrity of the chromatin structure. ${ }^{19}$ However, the precise enzymatic or biological activity of this domain remains enigmatic.

The two truncating mutations occur nearby or in the JmjC domain of PHF8 and are associated with a specific form of XLMR. Interestingly, mutations in families with XLMR have been found in the JARIDIC gene (MIM 314690), which also harbours JmjC and PHD finger domains. ${ }^{20}$ In the JARIDIC gene, several disease causing mutations in XLMR families have been described that strengthen the importance of this gene family in the aetiology of mental retardation.

In summary, we have shown that truncating mutations in the PHF8 gene cause either mild to borderline mental retardation associated with cleft lip/palate (XLMR-cleft lip/ cleft palate) or non-specific XLMR. PHD finger proteins are suspected of modifying and regulating the structure of the DNA, and therefore play a critical role in the regulation of transcription. The association of PHF8 with mental retardation and midline defects highlights the importance of this process, specifically during brain development and midline formation. In further studies we will aim to characterise the specific function of PHF8 and to understand the consequences of alterations in its function.

\section{GENBANK ACCESSION NUMBERS}

Human PHF8 mRNA accession number NM 015107

Human KIAA1111 mRNA accession number AB029034

Human PHF8 protein accession number NP 055922

Mouse Phf8 mRNA accession number AK12 2447

Mouse Phf8 protein accession number BAC65729

BAC clone RP13-444K19 accession number AL732374

\section{ACKNOWLEDGEMENTS}

We thank the patients and their families for their efficient cooperation in this study. We also thank B Jauffrion for the establishment of lymphoblastoid cell lines and Dr Doria Lamba for referring family 2 and the Galliera Genetic Bank for storing patient's samples. This work was supported by grants from INSERM, Fondation France Telecom, Fondation pour la Recherche Médicale (FL fellowship), GIS Maladies Rares No A02107GS, the $5^{\text {th }}$ European Union Framework (RTD project QLRT-2001-01810), Telethon Italia (Grant C51), NICHD (HD26202 to CES), and in part by the South Carolina Department of Disabilities and Special Needs (SCDDSN).

\section{Authors' affiliations}

F Laumonnier*, S Holbert*, N Ronce, C Moraine, S Briault, INSERM U619 "Génétique de l'autisme et des déficiences mentales", Faculté de Médecine, Université François Rabelais, Tours, France

F Faravelli, Genetica Umana, Ospedale Galliera, Genova, Italy S Lenzner, H-H Ropers, Max-Planck-Institute for Molecular Genetics, Berlin, Germany

C E Schwartz, Greenwood Genetic Center, Gregor Mendel Circle, Greenwood, South Carolina, USA

$\mathrm{J}$ Lespinasse, Laboratoire de Génétique Chromosomique, $\mathrm{CH}$ Chambéry, France

H Van Esch, J-P Fryns, Centre for Human Genetics, University of Leuven, Belgium

D Lacombe, C Goizet, Department of Medical Genetics, CHU Pellegrin, Bordeaux, France

F P-D Tuy, J Chelly, Institut Cochin, CHU Cochin, Paris, France

H van Bokhoven, B C J Hamel, Department of Human Genetics,

University Medical Centre, Nijmegen, Netherlands

Competing interests: none declared

*These authors contributed equally to the work
Correspondence to: Dr Sylvain Briault, INSERM U619, Génétique de l'autisme et des déficiences mentales, Faculté de Médecine 10, Bd Tonnellé BP 3223, 37032 Tours cedex 1, France; briault@med.univtours.fr

Received 19 November 2004

Revised version received 19 January 2005

Accepted for publication 20 January 2005

\section{REFERENCES}

1 Herbst DS, Miller JR. Nonspecific X-linked mental retardation II: the frequency in British Columbia. Am J Med Genet 1980;7:461-9.

2 Stevenson RE, Schwartz CE. Clinical and molecular contributions to the understanding of X-linked mental retardation. Cytogenet Genome Res 2002;99:265-75

3 Chiurazzi P, Tabolacci E, Neri G. X-linked mental retardation (XLMR): from clinical conditions to cloned genes. Crit Rev Clin Lab Sci 2004;41:117-58.

4 Chelly J, Mandel JL. Monogenic causes of X-linked mental retardation. Nat Rev Genet 2001;2:669-80.

5 Ropers HH, Hamel BC. X-linked mental retardation. Nat Rev Genet 2005;6:46-57.

6 Bienvenu $T$, Poirier K, Friocourt $G$, Bahi N, Beaumont D, Fauchereau $F$, Ben Jeema L, Zemni $R$, Vinet $M C$, Francis $F$, Couvert $P$ Gomot $M$, Moraine $C$, van Bokhoven H, Kalscheuer V, Frints S, Gecz J, Ohzaki K, Chaabouni H, Fryns JP, des Portes V, Beldjord C, Chelly J. ARX, a novel Prd-class-homeobox gene highly expressed in the telencephalon, is mutated in X-linked mental retardation. Hum Mol Genet 2002:11:981-91.

7 Stromme P, Mangelsdorf ME, Shaw MA, Lower KM, Lewis SM, Bruyere $H$, Lutcherath V, Gedeon AK, Wallace RH, Scheffer IE, Turner G, Partington M, Frints SG, Fryns JP, Sutherland GR, Mulley JC, Gecz J. Mutations in the human ortholog of Aristaless cause X-linked mental retardation and epilepsy. Nat Genet 2002;30:441-5.

8 Amir RE, van den Veyver IB, Wan M, Tran CQ, Francke U, Zoghbi HY. Rett syndrome is caused by mutations inX-linked MECP2, encoding methyl-CpGbinding protein 2. Nat Genet 1999;23:185-8.

9 Couvert P, Bienvenu T, Aquaviva C, Poirier K, Moraine C, Gendrot C, Verloes A, Andres C, Le Fevre AC, Souville I, Steffann J, des Portes V', Ropers HH, Yntema HG, Fryns JP, Briault S, Chelly J, Cherif B. MECP2 is highly mutated in X-linked mental retardation. Hum Mol Genet 2001;10:941-6.

10 Hanauer A, Young ID. Coffin-Lowry syndrome: clinical and molecular features. J Med Genet 2002;39:705-13.

11 Ropers HH, Hoeltzenbein M, Kalschever V, Yntema H, Hamel B, Fryns JP, Chelly J, Partington M, Gecz J, Moraine C. Nonsyndromic X-linked mental retardation: where are the missing mutations? Trends Genet 2003;19:316-20.

12 Laumonnier F, Ronce N, Hamel BC, Thomas P, Lespinasse J, Raynaud M, Paringaux C, van Bokhoven H, Kalscheuer V, Fryns JP, Chelly J, Moraine C, Briault S. Transcription factor SOX3 is involved in X-linked mental retardation with growth hormone deficiency. Am J Hum Genet 2002;71:1450-5.

13 Lubs HA, Schwartz CE, Stevenson RE, Arena JF. Study of X-linked mental retardation (XLMR): Summary of 61 families in the Miami/Greenwood study. Am J Med Genet 1996:64:169-75.

14 Siderius LE, Hamel BCJ, van Bokhoven $\mathrm{H}$, de Jager $\mathrm{F}$, van den Helm $\mathrm{B}$, Kremer H, Heineman-de Boer JA, Ropers HH, Mariman ECM. X-linked mental retardation associated with cleft lip/palate maps to Xp1 1.3-q21.3. Am J Med Genet 1999;85:216-20.

15 Goizet C, Bonneau D, Lacombe D. W syndrome: report of three cases and review. Am J Med Genet 1999;87:446-9.

16 Billuart P, Bienvenu T, Ronce N, des Portes V, Vinet MC, Zemni R, Roest Crollius H, Carrie A, Fauchereau F, Cherry M, Briault S, Hamel B, Fryns JP, Beldjord C, Kahn A, Moraine C, Chelly J. Oligophrenin-1 encodes a rhoGAP protein involved in X-linked mental retardation. Nature 1998;392:923-6.

17 Lower KM, Turner G, Kerr BA, Mathews KD, Shaw MA, Gedeon AK, Schelley S, Hoyme HE, White SM, Delatycki MB, Lampe AK, Clayton-Smith J, Stewart $H$, van Ravenswaay $C M$, de Vries BB, Cox B, Grompe M, Ross S, Thomas P, Mulley JC, Gecz J. Mutations in PHF6 are associated with BöriesonForssman-Lehmann syndrome. Nat Genet 2002;32:661-5.

18 Clissold PM, Ponting CP. JmjC: cupin metalloenzyme-like domains in jumonji, hairless and phospholipase A2beta. Trends Biochem Sci 2001;26:7-9.

19 Jensen LR, Amende M, Gurok U, Moser B, Gimmel V, Tzschach A, Janecke AR, Tariverdian G, Chelly J, Fryns JP, Van Esch H, Kleefstra T, Hamel B, Moraine C, Gecz J, Turner G, Reinhardt R, Kalscheuer VM, Ropers HH, Lenzner S. Mutations in the JARIDIC gene, involved in transcriptional regulation and chromatin remodeling, cause $X$-linked mental retardation. Am J Hum Genet 2005;76:227-36.

20 Dunwoodie SL, Henrique D, Harrison SM, Beddington RS. Mouse Dll3: a novel divergent Delta gene which may complement the function of other Delta homologues during early pattern formation in the mouse embryo. Development 1997; 124:3065-76. 